\title{
RUSSIA AS AN EMPIRE OF THE "FORM" IN CYPRIAN NORWID’S WRITINGS
}

[...] jakkolwiek nie każdemu wolno bratać się porównaniem z dostojną godnością Państwa Rzymskiego, nawet w jego wielkich upadkach - jednakowoż też same historii prawa pozwalają zwrócić uwagę, że:

o tej samej godzinie-historycznej dzisiejsze Rosyjskie Państwo obraża wszystkie aspiracje przyszłości Człowieczeństwa na zachodnim swym krańcu (w Wilnie i Warszawie) -

i o tejże godzinie zabiera w posiadanie wszystkie archiwa Ludzkości, całą przeszłość człowieczeństwa obchodzące, na Wschodzie (PWsz X, 108).

[...] although not every state is allowed to compare itself to the dignified grandeur of the Roman State, even in its great falls - however, the same laws of history allow one to point out:

in the same historical hour, today's Russian State offends all the aspirations of the future of Humanity at its Western end (in Vilnius and Warsaw) -

and in that hour, it takes possession of all the archives of Humanity which contain the whole history of humanity of the East.

The above words from Norwid's letter to Bronisław Zaleski, probably written in November 1877, reflect several important motifs from the poet's historiosophical reflections on Russia. It should be immediately stressed that many of these thoughts are not new or original, but they do belong to the trend of historiosophical summaries regarding the neighbouring state that participated in Poland's partitions. This trend was popular in $19^{\text {th }}$-century Polish literature (especially after the fall of the November Uprising). However, at the same time, these thoughts are strongly assimilated by Norwid and very consistent, inter alia, in terms of terminology with his other reflections on the philosophy of history. Additionally, we should not forget as long as we deal with historiosophy, we deal with a certain schematicity, a simplified view of reality that reflects only the general attitude of the thinker and writer towards the given phenomenon. 
In the quote cited above, among other things, there is a trace of geopolitical reflections on the specific location of Russia between the East and the West, ${ }^{1}$ its existence in that location and its aspirations. In his article entitled Rosja a Turcja [Russia vs Turkey], Mickiewicz gave such an assessment:

Russia believes that destiny itself has wanted it to rule over the East. It has always acted with this aim in mind, although it has subordinated its operations to the short-term benefits of European politics. Russia's immediate interest was to ensure that the principles of absolutism triumphed in Europe. ${ }^{2}$

Thus, Russia perceived in this way is consistently strengthening and expanding its position in the East and, at the same time, is more and more boldly reaching out to the West, while simultaneously, as Norwid wrote, "offending all the aspirations of the FUTURE of humanity." Russia appears to be the antithesis of the ideas of human freedom and respect, which have grown to become essential elements of Western European civilisation. Russia, not only in external politics, but in its very essence, appears as a symbol of enslavement, which it wants to impose on other nations. However, before the issue of enslavement and the lack of respect for man and humanity, which Norwid has often strongly stressed in relation to Tsarist Russia and will be examined more closely, it is also pertinent to discuss other motifs appearing in the quoted excerpt from the letter to Bronisław Zaleski, as they also shed important light on the issues that have already been raised in the introduction. Among them there is the issue of Russia as an empire of the "form."

${ }^{1}$ While evoking the notion of geopolitics and East-West relations in the context of Russia, it is worth noting at this point that the geopolitical visions of Poland's position in relation to Russia, which have been shaped to a large extent since the $18^{\text {th }}$ century, are still valid. In his book, entitled Poruszona mapa. Wyobraźnia polityczno-kulturowa polskiej literatury przełomu XX i XXI wieku [Kraków 2016], P. Czapliński noted: "In Polish culture, performing the act of describing Russia is a way of participating in the historical game. The game takes place on the East-West axis, crystallised in the $18^{\text {th }}$ century and frozen in the $20^{\text {th }}$ century. The traditional ends of the axis are marked by Moscow in the east and Paris in the west. However, the geographical poles are not only names here.

They overlap with ideas about Poland's development opportunities. These opportunities always remain dependent on external conditions, and thus are limited by these conditions. According to this image, the East means: autocratic forms of governing the state (lack of democracy), the loneliness of people in confrontation with the state structures (lack of rights), unfair distribution of wealth (economy managed by ideology), foreign policy based on violence. [...] The only historiosophical solution in such an arrangement was to escape from the East to the West, i.e. to democracy, to the laws which protect people in confrontation with the authorities and the state [...] (pp. 12-13).

2 A. Mickiewicz, Rosja a Trucja, [in:] IDem, Legion Polski. Trybuna Ludów, Dzieła, Vol. XII, Warszawa 1997, p. 270. 
The combination of the concepts: "Roman State" and "Russian State" is very characteristic. Among other things, this may connote the vision of Russia as the third Rome. Polish Romantic literature abounds in comparisons between Russia and ancient pagan Roma. This comparison is based on perceiving the signs of partitioning, tyranny, enslavement and also cultural secondarity in both Russia and ancient Rome. ${ }^{3}$ In the opening quote of this article, a particularly important concept is also that of the state itself. It turns out that Norwid often used it pejoratively. Among other things, the quote from List o Emigracji [The Letter on Emigration] of 1849 is crucial here:

Owóż naród jest wewnętrznym powinowatych ras sojuszem - tak jak państwo jest zewnętrznym blisko siebie będących ras s-kupieniem, s-traktatowaniem, z-niewoleniem. Naród tedy z ducha, a więc z woli i wolności jest [...], a państwo jest z ciała albo raczej z zewnętrza, z tego świata - z niewoli (PWsz VII, 27).

This nation is an internal alliance of related races - just as the state is an external concentration [lit. con-acquisition], con-treaty, enslavement of races existing close to each other. The nation is thus from the spirit, i.e. from the will and freedom [...], and the state is from the body, or rather from the outside, from this world - from slavery.

In order to fully understand the meaning of this statement by Norwid, we should refer to the poet's reflections on the relationship between the "word" and the "letter," reflecting the relationship between the "content" and the "form" or the body and the spirit. Norwid used these concepts on a metaphorical basis to reflect on various issues, including those related to literature and politics. ${ }^{4}$ The subject matter is overly broad and there is obviously no space for a thorough discussion. ${ }^{5}$ In the context of the state and the nation, the "word," and thus the "content," in Norwid's case refers to what builds a spiritual community (as a matter of fact, for the poet the word has a connection with the biblical "Word").

${ }^{3}$ Cf. M. Karamucka, Antyczny Rzym Norwida, Poznań 2016, pp. 108-125.

${ }^{4}$ Ibidem, pp. 91-99, 201-219.

5 On the subject of the "form" and "content" as well as the "word" and "letter," where the "letter" is a self-constraining form that expresses, similarly to the so-called "external word," the content of the "internal word" (Norwid distinguishes between the internal word, which originates in God, and the external word, which has human origin), understood by the poet as "akt psychiczny w duchu" [a mental act in spirit] (Stowo i litera [The Word and the Letter], PWsz VI, 311), Norwid wrote above all in the poem Rzecz o wolności stowa [On the Freedom of Speech], and the treatises Stowo i litera [The Word and the Letter], Milczenie [Silence], Rotacja stowa [The Rotation of the Word]. He also referred to this topic in his lectures entitled O Juliuszu Stowackim [On Juliusz Słowacki], in Notatki filologiczne [Philological Notes] and Notatki etno-filologiczne [Ethno-philological Notes]. 
The "Form," i.e. the "letter," in a way provides the political and legal framework within which a nation unites and organises itself. According to this idea, the nation derives from the "word," while the state is the "form," the "letter." For pragmatic reasons, a nation strives to adopt a "form," but the "form" is not its essence - the nation is still able to exist without it for some time. It is worth recalling the following fragment of Norwid's poem Niewola [Slavery]:

Wiem - że [...] naród formy miewa różne,

Jak człowiek szaty świetne i podróżne,

Lecz wiem, że formę gdy zdejmiesz z narodu,

To jeszcze będzie walczył wieki całe

O te, co w życiu ma, formy dostałe [...]

(DW IV, 51)

I know - that [...] a nation has different forms,

Like a man has great and traveling robes,

But I know that when you take the form off from the nation,

It is going to fight for centuries to come

For these forms it received in life [...]

In his article Naród - ojczyzna - społeczeństwo w myśli Cypriana Norwida, ${ }^{6}$ Rev. Antoni Dunajski stressed that over time Norwid seemed to see more and more strongly that a nation deprived of political existence is gradually losing its national consciousness. Although he often stressed the primary role of the "word," the poet did not depreciate the "form" (the state). ${ }^{7}$ However, the situation was different when this "form" did not remain in symbiosis with the spirit of the nation, it did not flow from it in a natural way, but was imposed on the nation or nations, and thus did not serve the "word," but took the supreme role. Norwid precisely recognised such a state entity in ancient Rome which was, in a way, "determined" by the "form," and which largely venerated the "form." He saw that such a state of affairs had to do with the specific genesis of Rome and the community of its peoples, its foundation above all on the letter of the law and an insufficient understanding of the idea of homeland, which the poet linked with the idea of nation. At its origins, as Norwid noted, Rome was not a community that took on the framework of a particular

\footnotetext{
${ }^{6}$ A. DunAJSKI, Naród - ojczyzna - społeczeństwo w myśli Cypriana Norwida, Lublin 2002, p. 15.

${ }^{7}$ It is also worth mentioning that in the treatise Stowo i litera [The Word and the Letter] Norwid defined the "word" as a combination of the "content" and the "form," proving that without the element of "form" the "word" would not really exist. Similar motifs, indicating the value of the "letter," i.e. "form," can also be found in Rzecz o wolności stowa [On the Freedom of Speech].
} 
"form," but a community which was created by that "form" ("Nie Rzym przez Rzymian postawiony, ale Rzymianie przez Rzym z różnych zbudowani plemion" [Rome was not established by the Romans, but the Romans were created by the Rome from different tribes]; Zarysy z Rzymu [Outlines from Rome]). ${ }^{8}$ According to this reflection, Rome itself was in a way a "form," a "letter." The source of its existence and unity was the state and the law. The "form" referred to here was to expand further within the empire, uniting within its frame peoples who were increasingly distant from one another - both territorially and culturally. There was no room for understanding the "word-nation." (Stowo i litera [The Word and the Letter], PWsz VI, 322). Following this path, it could be said that the sate not only suppressed the spirit of the nation, but also the spirit of freedom, humanity and the Word Incarnate itself which appeared on the arena of history in the times of and within the Roman Empire. Undoubtedly, therefore, when writing about the "Roman State" and the "Russian State," Norwid had in mind all these parallels between the notion of state and the notion of "form," with all its perceived negative connotations, i.e. the "form" which lost its connection with the content and became an end in itself. Perhaps it is also in this spirit in the following quotation from [Memoriat o prasie] [Memorial about the Press] that Norwid, who - interestingly enough — was seeking an alternative to the negatively marked terms Muscovite and Moscow, on several occasions described Tsarist Russia as the St. Petersburg State:

Do słowa M o s k a l, do słowa M o s kw a przywiązywanie ohydy jest zarazem przeciw-historyczną i przeciw-polityczną działalnością. Zdaje się, iż natomiast obowiązani jesteśmy używać określników, jak to: R z ą d P e t e r s bu r s k i, Państwo Petersburskie, ludność Państwa Petersburskiego, poniekąd rosyjską zwana... patriotyzm Państwa Petersburskiego itp. (PWsz VII, 136).

Associating disgust with the word Muscovite, with the word M o s cow is both an antihistorical and anti-political activity. It seems that instead we are obliged to use the terms such as the St. Petersburg Government, the St. Petersburg State, the people of the St. Petersburg State, apparently called Russian... the patriotism of the St. Petersburg State, etc.

The quoted excerpt was thoroughly analysed by Włodzimierz Torun in his article Rosja w myśli Norwida. This analysis, among other things, attempted to extract the political sense of the poet's terminological proposals. These issues, however, go beyond the historiosophical and philosophical motifs of the present article, concentrated on Russia as an empire of the "form." However, it is worth quoting here the following footnote of the poem Niewola [Slavery], in which

\footnotetext{
${ }^{8}$ M. KaramuCKa, Antyczny Rzym Norwida, pp. 96-97.
} 
Norwid used the term "state" to refer to Tsarist Russia, undoubtedly also in the negative sense mentioned here previously:

Cały nowy kodeks moskiewski dla Królestwa Polskiego jest tym brutalskim przeprowadzeniem idei państwa, które - bez uszanowania żadnego życia człowieka - stawa się organicznym prawem śmierci (DW IV, 51).

The whole new Moscow Code for the Kingdom of Poland is this brutal implementation of the idea of the state which - without any respect for human life - becomes an organic death law.

The poet meant the code which was imposed on the Kingdom of Poland [Congress Poland] in 1847, inter alia, in order to bring its criminal law in line with the Russian legislation. ${ }^{9}$ After an initial general remark, containing a very telling note on the "idea of the state" which is being "brutally" implemented, the poet continued with some detailed, critical remarks on the Moscow Code he cited. The same issues were also discussed in a letter to Juliusz Michelet of October 1851. It is worth mentioning that - as noted by Włodzimierz Torun - in his assessment of the Moscow Code, Norwid included several errors and inaccuracies. It turns out that it is difficult to find a basis for the statement made by the poet in both comments that there is no difference between offence and crime in the code. This issue can be summarised with a very apt conclusion by Włodzimierz Toruń: "Norwid's comment, although amateurish, not very precise, tried to capture the essence of the Russian system based on autarchy." 10

Commenting, at times somewhat subjectively, on the Moscow Code, Norwid certainly had in mind his strongly emphasised conviction that Russian "formalism" was in contradiction with the idea of respect for man. It is worth recalling a fragment of a letter to Konstancja Górska dated early 1852 (most probably from February), in which he referred to, among other things, the fact that throughout history some nations have continued to exist, while others have been lost or are only apparent, the reason being "nieuszanowanie osoby-czlowieka" [disrespect for the human person]:

Rosja nawet, która narodem nie jest, ale formalnym-stanem, która przeto wyjątek by tu stanowić mogła - Rosja nawet, tak jak sama formalna tylko jest, formalnie też ocenia człowieka, bowiem taksuje go na ruble.

Jednym słowem:

Tyle i takiej egzystencji naród ma, ile i jak jest w stanie człowieka uszanować (DW X, 391).

${ }^{9}$ W. Toruń, Rosja w myśli Norwida, [in:] Obraz Rosji w literaturze polskiej, eds. J. Fiećko, K. Trybuś, Poznań 2012, p. 199.

${ }^{10}$ Ibidem, p. 201. 
Even Russia, which is not a nation, but a formal state, which would be an exception here even Russia, just as it is only formal, formally assesses a man, because it appraises him by the value of roubles.

In a word:

The nation has as much and such an existence as much and how it is able to respect a man.

The list of intertwined weaknesses of Tsarist Russia is accompanied in this passage by materialism; this is another feature highlighted in Norwid's diagnosis of ancient pagan Rome. The connection between ancient pagan Rome ruled by emperors and Tsarist Russia was also directly expressed in the poem Niewola [Slavery] in the following passage:

Lecz tobie w Rosji, bracie Słowianinie,

Cezarska-formę przynieśli z Zachodu

I na rodzimej postawiono gminie,

Tak że Cesarstwo masz, nie masz Narodu!

(DW IV, 51)

But to you in Russia, my Slavic brother,

They brought Caesar's form from the West

And imposed on your native commune,

So that you have the Empire, you have no Nation!

Thus, we again have the antagonism between the "form" and the "content," the "state" and the "nation" - the latter so foreign to Russia and its empire. The "Caesar's form" brought from the West is the spirit of imperial, invasive Rome, i.e. the political similarities perceived by Norwid, but also the deeply ideological similarities and specific historical affinity between ancient Rome and Russia, as Krzysztof Trybuś put it - the characteristic "memory of Rome." 11

In the poem Niewola [Slavery], we also come across many other references to Russia. The work is, in a way, a historiosophical study of the notion of enslavement, which Russia appears to be an embodiment. As it has already been noted, in view of Norwid's philosophy analysed here, "formalism and enslavement" go hand in hand. Inter alia, in the poem we read:

Niewola - jest to formy postawienie

Na miejscu celu. - Oto uciśnienie ...

(DW IV, 48)

${ }^{11}$ K. Trybuś, Pamięć romantyczna. Studia nie tylko z przeszłościa, Poznań 2011, p. 183. 
Slavery - it is putting the form

in place of the aim. - It is oppression...

The mere perception of Russia as a political entity which is - as it were-imbued with a spirit of slavery was not that original. "Mickiewicz-as it was noted by Jerzy Fiećko in relation to the lectures at Collège de France-argued that during the reign of Ivan the Terrible, in the $16^{\text {th }}$ century, the Russian community lost the need to live in freedom, perpetuating the instinct of slavish submission to despotism, developed in the times of the Tartar captivity." ${ }^{12}$ Krasiński, on the other hand, wrote:

The Russians are the condemned of this world and, like the condemned, have only one consolation, their pride. In their heart they secretly admit their deep degradation; but they have neither sufficient reason nor human dignity to end it. They prefer to turn it into some ideal of slavery, and they claim and dream that sooner or later the whole world will be subjected to this slavery as they are now. Hence their passionate drive for conquests. ${ }^{13}$

This multifaceted theme of slavery in connection with Russia also returns in the works of many other thinkers and writers. The following words by Zygmunt Krasiński, imbued with a metaphor so similar to Norwid's, are also extremely interesting; in particular in the context of these considerations:

The essence and the principle of the Moscow schism is the authority of the secular power over the spiritual, i.e. the recognition of the body's superiority and control over the soul, the matter over the spirit, the form over the content - in other words, the enslavement of heaven carrying the shackles of earthly goals. ${ }^{14}$

It is also worth mentioning a fragment of Norwid's poem entitled Do wroga [To the Enemy]:

${ }^{12}$ The descriptive term for Russia, invoked by W. Torun, was taken from H. Kamieński’s book Rosja i Europa. Polska. Wstęp do badań nad Rosją i Moskalami (Warszawa 1999). J. FIEĆKo, Co zrobić z Rosja? Mickiewicz, Krasiński i inni, [in:] Obraz Rosji w literaturze polskiej, p. 145.

${ }^{13}$ Z. KRASIŃsKI, Memoriał do Napoleona III z października roku 1854, [in:] IDEM, Pisma filozoficzne i polityczne, Kraków 1912, pp. 553-554.

${ }^{14}$ IDEM, Uwagi nad dziełem o Rosji, Europie i Polsce, ibidem, p. 390; cf. P. CHLEBowsKi, Krasiński wobec Rosji, [in:] Zygmunt Krasiński - nowe spojrzenia, eds. G. Halkiewicz- Sojak, B. Burdziej, Toruń 2001, p. 138. 
Niech roz-niewoli się ta ciemna góra,

Wrogi!... do nogi broń!... kto jeszcze człowiek, A bryłę-lodu na kosy!... i hurra!...

(PWsz I, 373-374)

Let this dark mountain de-enslave itself,

Enemy!... order arms!... who else is yet human,

And put a lump of ice on the scythes!... and hooray!...

In the poem Niewola [Slavery], there was also a reference to Siberian captivity. Once again, Norwid used in it the image of a peculiar battle between the spirit and the "form":

To - ród (ta w zamian historyczna gmina),

Iż poza sobą cel ma w duchu-rodu

Ustawne z forma Carstwa boje wszczyna;

On na wygnaniu blednieć idzie z głodu,

Albo na taczkach kona na Syberii,

Lub się przeradza w służalczej liberii...

(DW IV, 64)

This is - a family (this historical commune in return),

Cause beyond itself it has an aim in the spirit of the people

To start constant fights with the form of the Tsardom;

In exile it fades out of hunger,

Or dies on a wheelbarrow in Siberia,

Or it transforms in a servile livery...

According to Norwid, the mentioned communities built by families were important pillars of the nation's spirit and tradition. The image of Russia as "a huge sensory force not inspired by the spirit" is, as Włodzimierz Torun noted, one of the more permanent stereotypes not only in the $19^{\text {th }}$ century. ${ }^{15}$ An additional remark from Niewola [Slavery] is extremely interesting in the context of Norwid's reflections on Russia, which appears to honour the "form."

Naród że cierpi, więc nie jest ideją,

Lecz jest wcieleniem żywym, organicznym,

Istota rzeczy. - Czuć ją, poznać chcę ją...

I oto z starym światem politycznym

Już od kolebki do boju powstawam -

${ }^{15}$ W. ToRuŃ, Russia w myśli Norwida, p. 203 
Gdyż rzekł: ,Narody tworze, bo wykrawam.”

(DW IV, 59)

The nation suffers, so it is not an idea,

But it is a living, organic incarnation,

The essence of things. - I want to feel it, know it...

And here with the old political world

From the cradle I have been rising to the battle -

Because he said: "I create nations because I cut out."

The last verse contains the essence of what has been mentioned above about Norwid's perception of the expansive, possessive states which set themselves the "form" as their goal and impose it on other nations under their influence. Norwid visually and aptly compared the action of these possessive states to the ruthless cutting out of new shapes with a form. It is a metaphor for introducing new orders and rules without considering the existing conditions. In the quote above, Norwid referred directly to Russia. There are also, as it seems, allusions to ancient Rome, hinted by the phrase "the old political world." When analysing the meaning of this phrase, it is worth mentioning, among other things, the following remark from Notatki z mitologii [Notes on Mythology]: "Grecja jest jeszcze jak Polska do Państwa Rzymskiego młodziuchną, kiedy cywilizacja Azji i Egiptu jest jak Państwo Rzymskie" [Greece is still young like Poland to the Roman State, while the Asian civilisation and Egypt is like the Roman State] (Notatki z mitologii, PWsz VII, 255). Greece, whose culture developed prior to the foundation of Rome, was shown here by Norwid as "young" to Rome. In terms of its youth, the poet also juxtaposed Greece with Poland. Such an approach, as far as the chronology of the history of these countries and nations is concerned, cannot be explained unless Norwid wanted to distinguish between the ideas of the old and the new world, i.e. the materialised, pagan reality, and the world of Christian values or those close to Christianity, concentrated not on the "form," i.e. on the "letter," but on the "word," spirit. In his view of history, Norwid often perceived Greece as an anticipation of Christianity, which is a separate, important motif. It is worth stressing that such an eloquent comparison of Greece to Poland in the quote above shows again the mutual similarity of their oppressors, i.e. Rome and Russia, respectively. Thus, pagan Rome and Tsarist Russia are also linked by the fact that they are countries of "old" ideas and political orders. The simple chronology gives way here to Norwid's historiosophical vision, ${ }^{16}$ according to which

${ }^{16}$ In the poet's vision, the "Epochs," among which Norwid distinguished the epochs of Legend, Epic, Story, Anecdote and Revolution, just as the "elements" manifested a distorted chronology 
individual nations are on the side of certain ideas, some of which belong to the old world and others to the new one. Hence Russia may be as old as Rome, which appears to be older than Greece that is almost as young as Poland. ${ }^{17}$

The picture of Russia presented here is an element of Norwid's historiosophical reflection focused on the antagonism between the Polish nation and imperialist Russia. The poet highlighted here those features of the tsarist, possessive empire which were also stressed by many other Polish writers and thinkers of that time. However, everything was deeply rooted in Norwid's metaphor, based on the opposition of the "word" and the "letter," the "content" and the "form." The reflections on Russia presented in this article are not just some detached thoughts of the poet, but should be rather seen as part of his more complex vision of history and philosophy of history, not only that of Poland, but also Europe or even the world. This is shown, inter alia, by the mentioned heterogeneous comparison of pagan, ancient Rome to Tsarist Russia.

\section{REFERENCES}

Norwid C., Pisma wszystkie [Collected Writings], compiled, edited, introduced and critically annotated by J.W. Gomulicki, Vols. I-XI, Warszawa 1971-1976.

Norwid C., Poematy 2, compiled by S. Sawicki, P. Chlebowski, Dzieła wszystkie [The Complete Works], Vol. IV, Lublin: TN KUL, 2011.

Norwid C., Listy 1, 1839-1854, compiled by J. Rudnicka, Dzieła wszystkie, Vol. X, Lublin: TN KUL, 2008.

Chlebowski P., Krasiński wobec Rosji, [in:] Zygmunt Krasiński - nowe spojrzenia, ed. G. Halkiewicz-Sojak, B. Burdziej, Toruń 2001, pp. 131-144.

Czapliński P., Poruszona mapa. Wyobraźnia polityczno-kulturowa polskiej literatury przełomu XX i XXI wieku, Kraków 2016.

Dunajski A., Naród - ojczyzna - społeczeństwo w myśli Cypriana Norwida, Lublin 2002.

FiećKo J., Co zrobić z Rosją? Mickiewicz, Krasiński i inni, [in:] Obraz Rosji w literaturze polskiej, eds. J. Fiećko, K. Trybuś, Poznań 2012, pp. 137-157.

Karamucka M., Antyczny Rzym Norwida, Poznań 2016.

Krasiński Z., Memoriat do Napoleona III z października roku 1854, [in:] IDEM, Pisma filozoficzne i polityczne, Kraków 1912, pp. 551-567.

throughout history. He himself wrote in Milczenie [Silence] about this disorder, which could have been avoided only in an imaginary situation if "perturbacje w tej naszej historii nie były tak częste $\mathrm{i}$ szerokie, tudzież gdyby żywioły etnologiczne nie przeżywały nieraz epok i przeto nie nadwerężały porządku chronologicznego (...)" [the perturbations in our history had not been so frequent and vast, or if the ethnological elements had not often lived through epochs and therefore had not strained the chronological order (...)]. (PWsz VI, 248).

${ }_{17}$ M. KaramucKa, Antyczny Rzym Norwida, pp. 113-114. 
Krasiński Z., Uwagi nad dziełem o Rosji, Europie i Polsce, ibidem, pp. 389-396.

Mickiewicz A., Rosja a Turcja, [in:] IDEM, Legion Polski. Trubuna Ludów, Dzieła, Vol. XII, Warszawa 1997, pp. 268-273.

Toruń W., Rosja w myśli Norwida, [in:] Obraz Rosji w literaturze polskiej, pp. 195-212.

TrYbuś K., Pamięć romantyczna. Studia nie tylko z przeszłościa, Poznań 2011.

\title{
RUSSIA AS AN EMPIRE OF THE "FORM" IN CYPRIAN NORWID'S WRITINGS
}

\author{
$\mathrm{S}$ u m m a r y
}

The aim of the article is to analyse Norwid's historiosophical reflections on Russia, in which the key role is played by metaphors based on the relationship between the "form" and the "content." This metaphoricity is reflected in the popular motif in the poet's works, which is based on the relationships: the "word" - the "letter," and the "spirit" - the "body." In the analysed fragments, mainly from the poem Niewola [Slavery], Tsarist, imperialist Russia appears as an empire of the "form," which in this case is supposed to mean the dominance of formalism and universally understood enslavement over the spiritual content. In Norwid's eyes, Russia, similarly to imperial Rome, stands in a clear opposition to the spirit of freedom, nation or humanity. The poet's vision reflects the popular trends in the $19^{\text {th }}$-century literature.

Key words: Russia; Poland; “form”; empire; state; nation; historiosophy; slavery; freedom.

Translated by Rafat Augustyn

Magdalena Karamucka - PhD in Humanities, Faculty of Polish and Classical Philology, Adam Mickiewicz University in Poznań; e-mail: kamagdalena@gazeta.pl 